\title{
Perbandingan Kemampuan Kriteria WHO 1997 dan Klasifikasi DENCO dalam Diagnosis dan Klasifikasi Infeksi Dengue
}

\author{
Kiki MK Samsi, Evelyn Phangkawira, Tatang K Samsi \\ Fakultas Kedokteran Universitas Tarumanagara- Rumah Sakit Sumber Waras, Jakarta
}

\begin{abstract}
Latar belakang. Sejalan dengan kemajuan ilmu pengetahuan, spektrum klinis infeksi dengue semakin luas dan bervariasi yang diikuti oleh beberapa klasifikasi infeksi dengue baru. Sejauh mana Kriteria WHO-1997 dan klasifikasi baru ini mampu mendeteksi infeksi dengue pasien di RS Sumber Waras, belum pernah dinilai. Tujuan. Membandingkan kesesuaian antara hasil konfirmasi laboratorium untuk infeksi dengue dengan kriteria WHO-1997, Klasifikasi DENCO, dan modifikasi WHO-1997 di RS Sumber Waras. Selain itu dinilai kemampuan ketiga kriteria/klasifikasi dalam mengelompokkan spektrum klinis infeksi dengue.

Metode. Merupakan penelitian diskriptif retrospektif dengan menggunakan data penelitian kami terdahulu (cluster study untuk dengue).

Hasil. Dalam periode tahun 2004-2008, terdapat 107 subjek penelitian terdiri 98 kasus infeksi virus dengue (serologi dan/atau virology positif) dan 9 sakit namun bukan kasus infeksi virus. Data menunjukkan bahwa dari 98 kasus terbukti infeksi dengue, 96 sesuai dengan Kriteria WHO 1997, 97 sesuai Klasifikasi Denco, dan 97 sesuai Modifikasi WHO-1997 di RS Sumber Waras. Terdapat 24 subjek yang tidak dapat diklasifikasikan dengan kriteria WHO 1997 yang ternyata 19 subjek dengue dengan tanda peringatan dan 5 subjek dengue berat berdasarkan Klasifikasi DENCO, sedangkan dengan modifikasi WHO-1997 RSSW (perdarahan bukan syarat mutlak), didapat 19 subjek DBD, SSD 2 subjek, DBD ensefalopati 1 subjek, dan SSD ensefalopati 2 subjek.

Kesimpulan. Kriteria WHO-1997 masih merupakan kriteria yang sesuai dalam diagnosis infeksi dengue, namun untuk dapat mengelompokan spektrum klinis infeksi dengue perlu dipertimbangkan agar manifestasi perdarahan tidak digunakan sebagai syarat mutlak. Sari Pediatri 2011;12(5):335-41.
\end{abstract}

Kata kunci: dengue, kriteria, WHO, DENCO

\section{Alamat korespondensi:}

Dr. Kiki M.K Samsi, Sp.A. Bagian Ilmu Kesehatan Anak, Rumah Sakit Sumber Waras, Jakarta. Fakultas Kedokteran, Universitas Tarumanagara, Jakarta

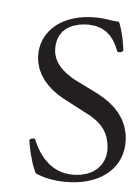

ejak pertama kali ditemukan pada tahun 1823 hingga kini infeksi virus dengue menunjukkan peningkatan insidens. Selama ini, sebagai acuan klinis diagnosis dan klasifikasi infeksi dengue, digunakan kriteria WHO tahun 1986 dan diperbaharui tahun 1997. Kriteria WHO 1997 
mengklasifikasikan infeksi dengue menjadi demam dengue, demam berdarah dengue dan sindrom syok dengue. ${ }^{1}$ Namun sejalan dengan peningkatan kualitas pelayanan kesehatan, kemajuan ilmu pengetahuan di bidang virologi, dan pemahaman interaksi virus dengan respons tubuh, maka spektrum klinis infeksi dengue menjadi semakin bervariasi, yaitu infeksi asimtomatik, demam dengue, demam berdarah dengue, manifestasi perdarahan berat, gangguan organ spesifik yang berat (gagal hati, ensefalopati/ensefalitis dengue,

Alamat korespondensi:

pankreatitis, transveres myelitis, miokarditis, infark myocardium, irreversible myositis). ${ }^{23}{ }^{4-6}$ Kondisi tersebut menyebabkan keraguan akan akurasi Kriteria WHO 1997 dan beberapa ahli kemudian memodifikasi kriteria WHO 1997, termasuk klasifikasi DENCO yang berbeda dengan klasifikasi WHO 1997 dan diusulkan menjadi kriteria baru WHO. ${ }^{57-12}$ Sampai saat ini di RS Sumber Waras belum diteliti apakah Kriteria WHO 1997 masih sesuai dengan konfirmasi laboratorium untuk diagnosis infeksi dengue dan mampu mengelompokan spektrum klinis infeksi dengue serta membandingkannya dengan klasifikasi DENCO.

Mengingat perlunya kesepakatan dalam menerapkan kriteria diagnosis dan kriteria manifestasi klinis infeksi dengue diberbagai tingkat sarana kesehatan di Indonesia khususnya di RS Sumber Waras, maka kami melakukan penelitian dengan membandingkan kesesuaian antara hasil konformasi laboratorium untuk infeksi dengue dengan ketiga kriteria/klasifikasi yaitu kriteria WHO 1997, DENCO study, dan kriteria WHO 1997 yang lazim digunakan oleh klinisi di RS Sumber Waras (modifikasi WHO 1997 di RS Sumber Waras). Disamping itu akan didiskriptifkan kemampuan ketiga kriteria/klasifikasi dalam mengelompokan spektrum klinis infeksi virus dengue.

\section{Metode}

Telah dilakukan penelitian diskriptif yang menggunakan data rekam medis dan data penelitian cluster penyakit infeksi dengue di RS Sumber Waras.

\section{Subjek penelitian}

Subjek penelitian diambil dari subjek penelitian cluster study yang telah dilaksanakan sejak tahun 2005 hingga 2008. Subjek terdiri dari kasus indeks dan partisipans komunitas. Kasus indeks adalah pasien yang dirawat di RS Sumber Waras dan terbukti secara klinis serta laboratoris menderita infeksi virus dengue. Selanjutnya peneliti mendatangi tempat tinggal pasien dan mengikut sertakan 20 warga sekitar untuk menjadi subjek penelitian (partisipan komunitas)

Konfirmasi diagnosis infeksi virus dengue ditegakkan melalui pemeriksaan Elisa IgM anti dengue, hemaglutination inhibition, RT-PCR, dan isolasi virus yang dilakukan pada hari-hari yang berbeda. ${ }^{14}$ Tes Elisa IgM dan hemaglutination inhibition dinyatakan positif bila terdapat kenaikan titer antibodi sebesar 4 kali antara masa akut dan konvalesen. Pasien infeksi virus dengue adalah kasus indeks dan partisipan komunitas dengan bukti adannya viremia virus dengue, sedangkan subjek bukan pasien infeksi virus dengue adalah partisipan komunitas yang sakit namun tidak ditemukan adanya viremia virus dengue. ${ }^{1516}$

\section{Klasifikasi infeksi dengue yang diteliti}

Klasifikasi yang diuji adalah Kriteria WHO 1997, Klasifikasi DENCO, dan modifikasi kriteria WHO 1997 RSSW (Tabel 1a,1b,1c).

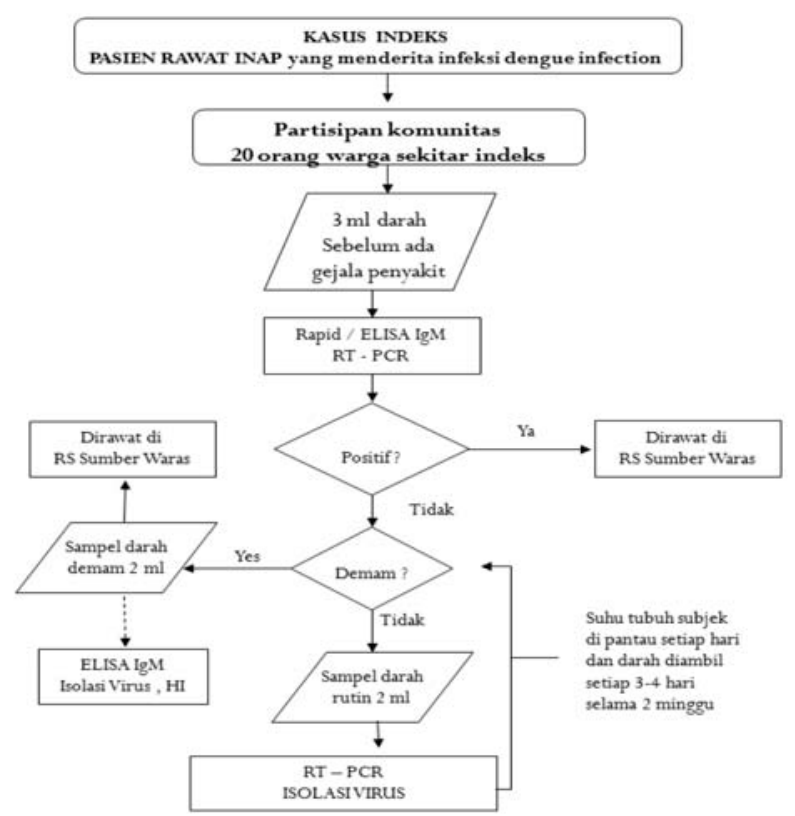

Gambar 1. Alur pemilihan subjek penelitian pada cluster study. $^{13}$ 
Tabel 1a. Kriteria WHO $1997^{1}$

i. Demam dengue (kasus probable)

Pasien dengan demam tinggi akut/mendadak dengan minimal dua dari gejala berikut ini: Sakit kepala, nyeri retroorbital, nyeri otot, nyeri sendi/nyeri tulang, rash, manifestasi perdarahan (Tes tourniquet positif, petekie, epistaksis), leukopenia. Kriteria laboratorium antibodi $\mathrm{HI} \geq 1.280$ atau tes ELISA IgM/IgG positif pada masa konvalesens atau adanya konfirmasi kasus dengue di daerah yang sama.

ii. Demam berdarah dengue

Pasien dengan 2 gejala klinis dan 2 gejala laboratorium sebagai berikut: Demam tinggi mendadak selama 2-7 hari, manifestasi perdarahan minimal torniket positif, jumlah trombosit di bawah 100.000/ cumm, hemokonsentrasi (peningkatan hematokrit $\geq 20 \%$ ) atau adanya bukti kebocoran plasma lain, seperti asites, efusi pleura, kadar protein/albumin/ kolesterol serum yang rendah. Albumin $\leq 3,5 \mathrm{ng} \%$ atau kolesterol $<100 \mathrm{mg} \%$ pada pasien anak nonmalnutrisi dipertimbangkan sebagai bukti tidak langsung adanya kebocoran plasma. Hepatomegali tidak dimasukkan di dalam definisi kasus, karena bergantung dari waktu pemeriksaan dan berbedabeda antar pemeriksa.

iii. Sindroma syok dengue

Memenuhi semua (ke-4) kriteria DBD, ditambah dengan bukti adanya kegagalan sirkulasi yang ditunjukkan dengan adanya nadi yang cepat dan lemah dan tekanan nadi yang menyempit $(<20 \mathrm{mmHg}(2,7 \mathrm{kPa}))$, atau dengan manifestasi hipotensi (berdasarkan nilai normal untuk umur), akral dingin, sembab dan gelisah

\section{Pengolahan data}

Perbandingan kesesuaian antara hasil konfirmasi laboratorium untuk infeksi dengue dengan ketiga klasifikasi dan kemampuan ketiga kriteria/klasifikasi dalam mengelompokkan spektrum klinis infeksi virus dengue akan dianalisis secara diskriptif.

\section{Hasil}

Dalam kurun waktu 2004-2008 telah dirawat 107 kasus memenuhi kriteria penelitian, yaitu 98 kasus infeksi
Tabel 1b. Klasifikasi DENCO ${ }^{12}$

i. Diagnosis presumtif dengue adalah dengan ditemukannya demam dan dua dari kriteria berikut, anoreksia dan mual, ruam, pegal-pegal atau nyeri, tanda peringatan, leukopenia, tes torniket $(+)$, ditambah dengan adanya riwayat orang sekitar yang terinfeksi dengue atau tinggal di / bepergian ke daerah endemis dengue.

ii. Dengue tanpa tanda peringatan memenuhi kriteria untuk diagnosis presumtif dengue tanpa tanda peringatan

iii. Dengue dengan tanda peringatan memenuhi kriteria untuk diagnosis presumtif dengue, dimana salah satu manifestasinya termasuk dalam tanda peringatan, yaitu nyeri perut atau tegang pada perut, muntah yang persisten, secara klinis didapatkan adanya akumulasi cairan, perdarahan mukosa, letargi atau gelisah, pembesaran hati $>2 \mathrm{~cm}$, secara laboratorium didapatkan adanya peningkatan hematokrit yang bersamaan dengan turunnya trombosit secara drastis

iv. Infeksi dengue berat.

- Kebocoran plasma berat yang mengakibatkan:

- Syok (sindrom syok dengue)

- Akumulasi cairan dengan distres pernafasan

- Perdarahan hebat

- Gangguan organ spesifik yang berat:

- Hati: peningkatan AST atau ALT $\geq 1000$

- SSP: gangguan kesadaran

- Jantung dan organ-organ lainnya

virus dengue (serologi dan/atau virologi positif) dan 9 kasus sakit namun bukan pasien infeksi virus dengue (serologi dan virologi negatif) dengan hasil uji diagnosis tertera pada Tabel 2.

\section{Pengelompokan spektrum klinis infeksi virus dengue}

Berdasarkan kriteria WHO 1997, dari 98 kasus infeksi dengue terdapat 38 pasien demam dengue, 28 DBD derajat I-II, 6 SSD, 2 bukan infeksi dengue dan 24 subjek tidak dapat diklasifikasikan (Tabel 3a dan 3b). Berbeda dengan kriteria WHO 1997, pada klasifikasi DENCO dan modifikasi kriteria WHO 1997 di RS Sumber Waras semua pasien dapat diklasifikasikan (Tabel 3a, 3b, 3c). 
Tabel 1c. Modifikasi kriteria WHO 1997 di RS Sumber Waras

- Modifikasi ini mewakili Kriteria dengue dari WHO 1997 yang digunakan oleh para klinisi di RS Sumber Waras dalam praktek sehari-hari berdasarkan penelitianpenelitian kami sebelumnya.

- Selain Kriteria WHO 1997, diagnosis klinis infeksi dengue di RS Sumber Waras juga mempertimbangkan kecenderungan peningkatan hematokrit disertai dengan penurunan trombosit, kejadian luar biasa atau endemisitas daerah tempat tinggal.

- Trombositopenia untuk infeksi dengue mempertimbangkan adanya kecenderungan penurunan trombosit dengan cut point $\leq 150.000 / \mu \mathrm{L}$

- Diagnosis demam berdarah dengue berdasarkan adanya kebocoran plasma yang ditandai dengan peningkatan hematokrit $\geq 20 \%$ (Hematokrit tertinggi dikurangi hematokrit pada masa konvalesen) dan/atau ditemukan adanya akumulasi cairan di jaringan (efusi pleura, ascites, dan pembengkakan kandung empedu). Pasien dengan gejala demam tanpa manifestasi perdarahan disertai trombositopenia dan hemokonsentrasi ditegakkan diagnosis klinis (presumptive) demam berdarah dengue.

- Sindroma syok dengue: Tidak ada perbedaan dengan Kriteria WHO 1997.

- Manifestasi lain adanya ensefalopati atau keterlibatan organ spesifik lainnya (misalnya pankreatitis).
Dari 24 subjek yang tidak dapat diklasifikasikan dengan kriteria WHO 1997, ternyata 19 pasien tergolong dengue dengan tanda peringatan dan 5 pasien dengue berat berdasarkan Klasifikasi DENCO. Subjek yang tidak dapat diklasifikasikan dengan Kriteria WHO 1997 adalah subjek yang memenuhi definisi demam dengue, terdapat bukti kebocoran plasma, namun tidak terdapat manifestasi perdarahan. Manifestasi perdarahan menjadi persyaratan kriteria WHO 1997 untuk klasifikasi demam berdarah dengue (derajat I -IV) sedangkan penelitian ini mendapatkan bahwa dari 58 subjek mengalami kebocoran plasma (sesuai untuk demam berdarah dengue) hanya 32 subjek yang mengalami perdarahan, sedangkan 26 pasien mengalami kebocoran plasma tanpa ada perdarahan.

Modifikasi kriteria WHO 1997 di RS Sumber Waras dapat mengelompokan 24 pasien kebocoran plasma menjadi 19 pasien demam berdarah dengue, sindrom syok dengue 2 pasien, demam berdarah dengue ensefalopati 1 pasien, dan sindrom syok dengue ensefalopati 2 pasien.

\section{Pembahasan}

Seiring dengan berkembangnya ilmu pengetahuan

Tabel 2. Kesesuaian hasil konfirmasi laboratorium dengan kriteria WHO 1997, klasifikasi DENCO, dan WHO 1997 di RS Sumber Waras

\begin{tabular}{lcc}
\hline \multirow{2}{*}{ Kriteria/Klasifikasi } & \multicolumn{2}{c}{ Konfirmasi laboratorium (virologi, serologi) } \\
\cline { 2 - 3 } & Terbukti infeksi dengue $(\mathrm{n}=98)$ & Tidak terbukti infeksi dengue $(\mathrm{n}=9)$ \\
\hline Kriteria WHO 1997 & 96 & 5 \\
Klasifikasi DENCO & 97 & 4 \\
Modifikasi kriteria WHO 1997 di & 97 & 8 \\
RS Sumber Waras & & \\
\hline
\end{tabular}

Tabel 3a. Perbandingan kriteria WHO 1997 dengan klasifikasi DENCO dalam mengelompokan spektrum klinis infeksi virus dengue

\begin{tabular}{lccccc}
\hline & \multicolumn{4}{c}{ Klasifikasi DENCO } \\
\cline { 2 - 6 } Kriteria WHO 1997 & $\begin{array}{c}\text { Bukan } \\
\text { dengue }\end{array}$ & $\begin{array}{c}\text { Dengue tanpa } \\
\text { tanda peringatan }\end{array}$ & $\begin{array}{c}\text { Dengue dengan } \\
\text { tanda peringatan }\end{array}$ & Dengue berat & Total \\
\hline Bukan infeksi dengue & 1 & - & 1 & - & 2 \\
Demam dengue & - & 14 & 24 & - & - \\
Demam berdarah dengue & - & - & - & 6 & 6 \\
Sindrom syok dengue & - & - & 19 & 5 & 28 \\
Infeksi dengue tidak terklasifikasikan & - & - & 72 & 11 & 98 \\
\hline Total & 1 & 14 & - & 28 \\
\hline
\end{tabular}


Tabel 3b. Perbandingan kriteria WHO 1997 dengan modifikasi kriteria WHO 1997 di RS sumber waras dalam mengelompokan spektrum klinis infeksi virus dengue

\begin{tabular}{lccccccc}
\hline \multirow{2}{*}{ Kriteria WHO 1997} & \multicolumn{7}{c}{ Modifikasi Kriteria WHO } \\
\cline { 2 - 7 } & $\begin{array}{c}\text { Bukan } \\
\text { dengue }\end{array}$ & $\begin{array}{c}\text { Demam } \\
\text { dengue }\end{array}$ & DBD & SSD & $\begin{array}{c}\text { DBD } \\
\text { ensefalopati }\end{array}$ & $\begin{array}{c}\text { SSD } \\
\text { ensefalopati }\end{array}$ & Total \\
\hline Bukan infeksi dengue & 1 & 1 & - & - & - & - & 2 \\
Demam dengue & - & 38 & - & - & - & - & 38 \\
Demam berdarah dengue & - & - & 28 & - & - & - & 28 \\
Sindrom syok dengue & - & - & - & 6 & - & - & 6 \\
Infeksi dengue tidak terklasifikasikan & - & - & 19 & 2 & 1 & 2 & 24 \\
\hline Total & 1 & 39 & 47 & 8 & 1 & 2 & 98 \\
\hline
\end{tabular}

Tabel 3c. Perbandingan kriteria WHO 1997 dengan klasifikasi denco dalam mengelompokan spektrum klinis infeksi virus dengue

\begin{tabular}{lccccc}
\hline & \multicolumn{5}{c}{ Klasifikasi DENCO } \\
\cline { 2 - 6 } $\begin{array}{l}\text { Modifikasi Kriteria WHO } \\
\text { 1997 di RSSW }\end{array}$ & $\begin{array}{c}\text { Bukan } \\
\text { dengue }\end{array}$ & $\begin{array}{c}\text { Dengue } \\
\text { tanpa } \\
\text { tanda } \\
\text { peringatan }\end{array}$ & $\begin{array}{c}\text { Dengue } \\
\text { dengan tanda } \\
\text { peringatan }\end{array}$ & $\begin{array}{c}\text { Dengue } \\
\text { berat }\end{array}$ & Total \\
\hline Bukan infeksi dengue & 1 & - & - & - & 1 \\
Demam dengue & - & 14 & 25 & - & 39 \\
Demam berdarah dengue & - & - & 47 & - & 47 \\
Sindrom syok dengue & - & - & - & 8 & 8 \\
DBD ensefalopati & - & - & - & 1 & 1 \\
SSD ensefalopati & - & - & - & 2 & 2 \\
\hline Total & 1 & 14 & 72 & 11 & 98 \\
\hline
\end{tabular}

di bidang patogenesis penyakit dan laboratorium virologi-serologi, para klinisi mendapatkan spektrum manifestasi klinis infeksi dengue menjadi lebih luas dan bervariasi. ${ }^{17} \mathrm{Hal}$ ini menyebabkan kesulitan dalam mendiagnosis infeksi dengue dan menimbulkan keraguan terhadap kemampuan (akurasi) kriteria WHO 1997. 5,9,11,18,19 DENCO Study membuat kriteria baru dalam upaya meningkatkan akurasi diagnosis infeksi virus dengue. ${ }^{12}$ Sedangkan di bagian Ilmu Kesehatan Anak RS Sumber Waras hanya memodifikasi kriteria WHO 1997 yang didasari atas penelitian-penelitian kami terdahulu. Elisa IgM anti dengue, hemaglutination inhibition, RT-PCR, dan isolasi virus dari bahan darah subjek yang diambil secara serial dalam beberapa hari. ${ }^{16}$

Penelitian kami menunjukkan bahwa kriteria WHO 1997 masih memiliki kemampuan yang baik dalam mendeteksi pasien terbukti infeksi virus dengue (true positive) Bahkan secara klinis sebanding dengan kesesuaian dua kriteria/klasifikasi lainnya yaitu klasifikasi DENCO dan modifikasi kriteria WHO

\section{7 di RS Sumber Waras}

Meskipun kriteria WHO 1997 mampu mendeteksi pasien infeksi virus dengue, kami mendapatkan kesulitan dalam mengelompokan 24 subjek yang sesuai dengan infeksi dengue demam 2-7 hari, trombosit $<100.000 /$ Ul, disertai kebocoran plasma (hemokonsentrasi atau bukti penumpukan cairan di jaringan) tetapi tidak menunjukkan manifestasi perdarahan. Kriteria WHO 1997 mensyaratkan minimal 2 manifestasi klinis dan 2 hasil laboratories (demam, perdarahan, gangguan sirkulasi trombositopenia $<100.000 / u L$, hemokonsentrasi atau penumpukan cairan di jaringan) maka ke-24 subjek ini tidak dapat diklasifikasikan dengan kriteria WHO 1997. Klasifikasi DENCO dan modifikasi WHO 1997 di RSSW tidak menjadikan manifestasi perdarahan sebagai syarat mutlak sehingga semua subjek yang terbukti menderita infeksi dengue dapat diklasifikasikan.

Jika kita menilai kembali dari sejarahnya, penyakit infeksi dengue pertama kali dilaporkan pada tahun 1823 saat terjadi outbreak (kejadian luar biasa) di dae- 
rah Indie Barat dan Afrika Timur yang dikenal dengan nama penyakit denga (aneh). Kemudian pada tahun 1897-1931 selama terjadi epidemi penyakit denga di Australia, Yunani, dan Taiwan dengan manifestasi klinis yang umumnya berat yaitu syok, manifestasi perdarahan, sampai dengan kematian. Pada tahun 1950 di Rumah Sakit Siriraj di Bangkok (Thailand) dilaporkan kasus-kasus yang terjadi setiap musim hujan yang kenal sebagai "purpura trombositopenia dengan kolaps kardiovaskular". Manifestasi klinis ini mirip dengan apa yang kita kenal sekarang sebagai sindrom syok dengue. Pada tahun 1954 Filipina juga melaporkan kasus yang serupa yang kemudian diberi nama Phillipines Hemorrhagic Fever. Baru pada tahun 1964 WHO menamakan penyakit yang sudah dilaporkan selama ini dengan nama dengue hemorrhagic fever (demam berdarah dengue). Rangkaian sejarah inilah yang menyebabkan kriteria WHO hingga saat ini menjadikan manifestasi perdarahan sebagai syarat klasifikasi untuk demam berdarah dengue.

Pengetahuan tentang patogenesis akhirnya menunjukkan bahwa penyebab terjadinya syok pada demam berdarah adalah adanya kebocoran plasma. Bahkan penelitian terbaru menunjukkan bahwa kebocoran plasma terjadi akibat adanya peregangan tight junction endotel yang bersifat reversible dan terjadi dalam waktu 24-72 jam saja. Segera setelah virus dapat dieliminasi dan sitokin (IL-8, TNF- $\alpha)^{20-}$ 22 dapat dinetralisasi, maka kontraksi otot endotel menghilang dan tight junction kembali seperti semula. Pemahaman ini didukung oleh hasil penelitian patologi anatomi yang menemukan bahwa pembuluh darah kasus infeksi dengue yang mengalami kebocoran plasma hanya menujukkan adanya edema ringan tanpa adanya kerusakan pembuluh darah (fragilitas kapiler). Patogenesis kebocoran plasma berbeda dengan patogenesis perdarahan yang disebabkan oleh adanya peningkatan fragilitas kapiler. Proses peningkatan fragilitas kapiler, sebagai akibat kerusakan pembuluh darah, melibatkan respon inflamasi yang lebih kompleks (peran I-CAM, V-CAM, dan komplemen). Dengan kata lain, perbedaan patogenesis memungkinkan adanya kasus demam berdarah dengue (didasari bukti kebocoran plasma) yang tidak menunjukkan adanya manifestasi perdarahan. ${ }^{22}$ Penelitian kami mendapatkan bahwa manifestasi perdarahan tampak pada $61(68,4 \%)$ di antara 107 subjek terbukti positif infeksi dengue. Bahkan dari 58 subjek yang mengalami kebocoran plasma hanya $34(58,6 \%)$ subjek yang mengalami perdarahan. Hal ini mendasari pemikiran apakah manifestasi perdarahan masih relevan untuk dimasukkan ke dalam syarat mutlak kriteria demam berdarah dengue WHO 1997.

Perbedaan pengelompokan juga terjadi pada subjek demam dengue (menurut Kriteria WHO 1997 dan Modifikasi Kriteria WHO 1997 di RSSW), karena mengalami nyeri perut dikelompokkan sebagai dengue dengan tanda peringatan. Kami memberikan terapi sesuai protokol demam dengue dan selama perawatan subjek ini tidak mengalami kebocoran plasma ataupun kelainan lain yang mengancam jiwa. Kami memandang perlunya penjelasan detail dalam klasifikasi DENCO tentang bentuk nyeri perut yang menunjukkan tanda peringatan. Selain itu kami juga menemukan subjek yang menderita ensefalopati/ensefalitis dan dikelompokan sebagai DBD ensefalopati dan SSD ensefalopati.

Kriteria WHO 1997 dan klasifikasi DENCO memiliki spesifisitas yang rendah dan lebih rendah daripada Modifikasi Kriteria WHO 1997 di RSSW. ${ }^{23}$ Baik Kriteria WHO 1997 ataupun Klasifikasi DENCO tidak mencantumkan penurunan trombosit sebagai syarat, sedangkan klasifikasi infeksi dengue oleh staf medis di RS Sumber Waras menggunakan penurunan trombosit dengan cutpoint $\leq 150.000 / \mu \mathrm{L}$ sebagai salah satu pertimbangan. ${ }^{12}$

Sampai saat ini Kriteria WHO 1997 masih memiliki kemampuan yang baik dalam menegakkan diagnosis infeksi dengue. Namun untuk dapat mengelompokan semua kasus yang terbuki infeksi dengue perlu dipertimbangkan agar manifestasi perdarahan tidak digunakan sebagai syarat mutlak.

\section{Daftar pustaka}

1. Organization WH. Dengue Hemorrhagic Fever: diagnosis, treatment, prevention and control, . Second edition ed. Geneva: WHO, 1997.

2. Lum LC, Lam SK, Choy YS, George R, Harun F. Dengue encephalitis: a true entity? Am J Trop Med Hyg 1996;54:256-9.

3. Soares CN, Cabral-Castro MJ, Peralta JM, Freitas MR, Puccioni-Sohler M. Meningitis determined by oligosymptomatic dengue virus type 3 infection: report of a case. Int J Infect Dis 2010;14:e150-2.

4. Lum LC, Lam SK, George R, Devi S. Fulminant hepatitis in dengue infection. Southeast Asian J Trop Med Public 
Health 1993;24:467-71.

5. Balmaseda A, Hammond SN, Perez MA, Cuadra R, Solano S, Rocha J, dkk. Short report: assessment of the World Health Organization scheme for classification of dengue severity in Nicaragua. Am J Trop Med Hyg 2005;73:1059-62.

6. Khan NA, Azhar EI, El-Fiky S, Madani HH, Abuljadial MA, Ashshi AM, dkk. Clinical profile and outcome of hospitalized patients during first outbreak of dengue in Makkah, Saudi Arabia. Acta Trop 2008;105:39-44.

7. Phuong CX, Nhan NT, Kneen R, Thuy PT, van Thien C, Nga NT, dkk. Clinical diagnosis and assessment of severity of confirmed dengue infections in Vietnamese children: is the world health organization classification system helpful? Am J Trop Med Hyg 2004;70:172-9.

8. Setiati TE, Mairuhu AT, Koraka P, Supriatna M, Mac Gillavry MR, Brandjes DP, dkk. Dengue disease severity in Indonesian children: an evaluation of the World Health Organization classification system. BMC Infect Dis 2007;7:22.

9. Deen JL, Harris E, Wills B, Balmaseda A, Hammond SN, Rocha C, dkk. The WHO dengue classification and case definitions: time for a reassessment. Lancet 2006;368:170-3.

10. Ng CF, Lum LC, Ismail NA, Tan LH, Tan CP. Clinicians' diagnostic practice of dengue infections. J Clin Virol 2007;40:202-6.

11. Kabra SK, Jain Y, Pandey RM, Madhulika, Singhal T, Tripathi P, dkk. Dengue haemorrhagic fever in children in the 1996 Delhi epidemic. Trans R Soc Trop Med Hyg 1999;93:294-8.

12. Organization WH. Dengue: Guidelines for diagnosis, treatment, prevention and control. Edisi ke-1. Geneva: WHO/TDR, 2009.

13. Charmagneg. Beckett HK, Indrafaisal, Nurhayati, Ratnatan, Susanawidjaja, dkk. Early Detection of Dengue Infections Using Cluster Sampling Around Index Cases Am. J. Trop. Med. Hyg 2005;72:6.

14. Pervin $M$, Tabassum S, Islam MN. Isolation and serotyping of dengue viruses by mosquito inoculation technique from clinically suspected cases of dengue fever. Bangladesh Med Res Counc Bull 2002;28:104-11.

15. Chan SY, Kautner I, Lam SK. Detection and serotyping of dengue viruses by PCR: a simple, rapid method for the isolation of viral RNA from infected mosquito larvae. Southeast Asian J Trop Med Public Health 1994;25:25861.

16. Kuno G, Gomez I, Gubler DJ. An ELISA procedure for the diagnosis of dengue infections. J Virol Methods 1991;33:101-13.

17. Murgue B, Deparis X, Chungue E, Cassar O, Roche C. Dengue: an evaluation of dengue severity in French Polynesia based on an analysis of 403 laboratoryconfirmed cases. Trop Med Int Health 1999;4:765-73.

18. Bandyopadhyay S, Lum LC, Kroeger A. Classifying dengue: a review of the difficulties in using the WHO case classification for dengue haemorrhagic fever. Trop Med Int Health 2006;11:1238-55.

19. Gupta P, Khare V, Tripathi S, Nag VL, Kumar R, Khan MY, dkk. Assessment of world health organization definition of dengue hemorrhagic fever in North India. J Infect Dev Ctries 2010;4:150-5.

20. Talavera D, Castillo AM, Dominguez MC, Gutierrez AE, Meza I. IL8 release, tight junction and cytoskeleton dynamic reorganization conducive to permeability increase are induced by dengue virus infection of microvascular endothelial monolayers. J Gen Virol 2004;85:1801-13.

21. Dewi BE, Takasaki T, Kurane I. In vitro assessment of human endothelial cell permeability: effects of inflammatory cytokines and dengue virus infection. $J$ Virol Methods 2004;121:171-80.

22. Lei HY, Yeh TM, Liu HS, Lin YS, Chen SH, Liu CC. Immunopathogenesis of dengue virus infection. J Biomed Sci 2001;8:377-88.

23. Martinez RA, Diaz FA, Villar LA. Evaluation of the world health organization clinical definition of dengue. Biomedica 2005;25:412-6. 